\title{
Estimation of Micronutrient Contents in Traditional Green Leafy Vegetables and Their Potential Contribution to Dietary Recommended Intakes
}

\author{
Faustina Dufie Wireko-Manu ${ }^{1,2, *}$, Shirley Isibhakhomen Ejoh ${ }^{1,3}$, David Page ${ }^{1}$, \\ Catherine M. G. C. Renard ${ }^{1}$ \\ ${ }^{1}$ UMR408 SQPOV «Sécurité et Qualité des Produits d'Origine Végétale», INRAE, Avignon Université, Avignon, France \\ ${ }^{2}$ Department of Food Science and Technology, Kwame Nkrumah University of Science and Technology, Kumasi, Ghana \\ ${ }^{3}$ Department of Human Nutrition, Faculty of Public Health, College of Medicine, University of Ibadan, Ibadan, Nigeria
}

Email address:

fdbaah $a$ yahoo.com (F. D. Wireko-Manu), fdwireko-manu.cos $a$ knust.edu.gh (F. D. Wireko-Manu)

${ }^{*}$ Corresponding author

\section{To cite this article:}

Faustina Dufie Wireko-Manu, Shirley Isibhakhomen Ejoh, David Page, Catherine M. G. C. Renard. Estimation of Micronutrient Contents in Traditional Green Leafy Vegetables and Their Potential Contribution to Dietary Recommended Intakes. Journal of Food and Nutrition Sciences. Vol. 8, No. 1, 2020, pp. 15-23. doi: 10.11648/j.jfns.20200801.13

Received: February 21, 2020; Accepted: March 23, 2020; Published: April 7, 2020

\begin{abstract}
Micronutrient deficiency is a public health problem even though vegetable consumption could avert it. Vitamin $C$ [Ascorbic acid (AA) and dehydroascorbate (DHAA)], $\beta$-carotene, lutein and vitamin B9 contents in seven traditional green leafy vegetables (raw and cooked) from Ghana were determined, to identify good sources and their potential contribution to Dietary Recommended Intakes. The micronutrients were quantified using spectrofluorimetric and HPLC/DAD analytical systems. Vitamin C content of samples ranged between 7.2 and $161 \mathrm{mg} / 100 \mathrm{~g}$ fresh weight. $\beta$-carotene content was within the ranges of 2.97 to $10.35 \mathrm{mg} / 100 \mathrm{~g}$, Lutein 13.5 to $31.6 \mathrm{mg} / 100 \mathrm{~g}$ and total folate 18 to $146 \mu \mathrm{g} / 100 \mathrm{~g}$. Lutein and $\beta$-carotene were in variable relative proportions (L/C from 1.6 to 6); Solanum macrocarpon and Amaranthus hybridus samples were particularly rich in lutein and $\beta$-carotene, respectively. Losses between 45 and $94 \%$ were observed for vitamin C, between 15 to $81 \%$ for $\beta$-carotene with the exception of an increase in Solanum macrocarpon and 17 to $80 \%$ for lutein under boiling. Similar drastic losses were recorded in microwaved samples; however, losses in lutein and folate were comparatively lower. The traditional green leafy vegetables studied were found to be very rich in the studied micronutrients, but cooking led to considerable losses. However, the cooked vegetables represent non-negligible sources of folate, good source of lutein and could provide up to $97 \%$ and $90 \%$ vitamin A and C Recommended Dietary Intakes respectively, when a $100 \mathrm{~g}$ is consumed. Improved cooking methods over the traditional methods of preparation are essential for retaining more micronutrients, for the benefit of consumers.
\end{abstract}

Keywords: Traditional Green Leafy Vegetables (TGLV), Ascorbic Acid, $\beta$-Carotene, Lutein, Folate, Cooking Methods

\section{Introduction}

Vegetables are well known to be good sources of micronutrients, such as ascorbic acid, $\beta$-carotene, lutein, vitamin B9 among others, which confer good health to consumers. While ascorbic acid enhances non-heme iron absorption and reduces the risk of many viral diseases, carotenoids ( $\beta$-carotene and lutein) are needed for stronger immune systems and good eyesight while vitamin B9 (folic acid) plays a key role in cell division, differentiation and regulation. Micronutrient deficiencies have significant effect on health, and thus pose serious economic implications on a nation in terms of medical cost and reduced productivity [1].

Ghana has a rich diversity of green leafy vegetables (both cultivated and non-cultivated) which are utilized as integral food sources, especially as major ingredients in soups, sauces and salads. Most traditionally cultivated green leafy vegetables (TGLVs) commonly consumed in Ghana include leaves of Xanthosoma saggitifolium, Corchorus olitorius, Solanum 
macrocapon, Amaranthus hybridus among others. However, only few of the known TGLVs are consumed routinely in specific areas of the country because they have been part of their food and cultural systems for a long time [2].

Other consumed green leafy vegetables which are not cultivated include Launaea taraxacifolia, Nephrolepis undulate, Talinum triangulare, A. viridis among others. Preference of vegetables especially in the urban areas and among the youth, tend to shift to more exotic and expensive ones such as cabbage, lettuce, spring onions, carrot and cucumber, to the disadvantage of traditional green leafy vegetables that are cultivated or grown in the wild. Knowledge of the nutritional contributions of TGLVs is not widespread. The trend has contributed to increased micronutrient deficiencies and diet related noncommunicable diseases [4]. The per capita intake of fruits and vegetables in developing countries is still considered far below the $400 \mathrm{~g}$ per capita per day recommended by WHO and FAO [3]. The good news is that, there is increased research attention on traditional underutilized food crops due to their potential to contribute to feeding the ever increasing world population and attaining the Sustainable Development Goal number two (2), which seeks to "end hunger, achieve food security, improve nutrition and promote sustainable agriculture" by 2030. This goal is not merely to double production of agricultural commodities but also to ensure the already existing yet underutilized species are domesticated, preserved and utilized to the utmost degree.

Reports show that traditional green leafy vegetables have comparable good micronutrient contents and are more affordable than the exotic cultivated ones [5-6]. Until recently, most efforts in Ghana have focused on vitamin supplementation to combat micronutrient malnutrition, but this is donor dependent. Vegetables consumption in diverse forms have therefore been proposed as one of the important sources of micronutrients to advocate for, especially when the traditional diets made from unrefined ingredients, including vegetables, are shifting to more refined, processed and simple sugar food products. Smith and Eyzaguirre, [2], Schonfeldt and Pretoriuos, [10], Jaarsveld et al. [11] and others have reported on the nutritional composition of African vegetables, and given an indication of the huge potential of overcoming micronutrient malnutrition with its associated health challenges at a negligible cost with consumption of indigenous vegetables. Identification of traditional vegetables with potential to contribute to micronutrient status of Ghanaians will be a more sustainable means of tackling health related problems associated with their deficiencies.

With the exception of a few vegetables used in salads, virtually all traditional green leafy vegetables in Ghana are cooked to increase palatability, reduce bitterness and remove itchiness. However, their nutrient concentrations are affected during cooking [7-9]. This study, therefore, aimed at estimating the micronutrient contents of traditional green leafy vegetables from Ghana and their potential contribution to dietary recommended intakes. The data obtained will be valuable for educating the public about micronutrient rich traditional green leafy vegetables in order to encourage their consumption, recommend appropriate preparation methods and prevent health consequences of micronutrient deficiencies.

\section{Materials and Methods}

\subsection{Materials}

\subsubsection{Sample Collection and Preparation}

Seven green leafy vegetables were sourced from a market in Ejisu, Kumasi (a forest zone between the North and the South of Ghana) and transported under cold chain to Avignon, France. Within $36 \mathrm{~h}$, edible portions (leaves and stalk) of the raw vegetables were sorted, mixed evenly and weighed in three (3) sets of $150 \mathrm{~g}$ each. The first group was stabilized by grinding in liquid nitrogen (A11 analytical mill, IKA, Staufen, Germany) into fine powder. The second group was microwaved at full power with $20 \mathrm{ml}$ of water for $10 \mathrm{~min}$, allowed to cool and also ground in liquid nitrogen. The third set of vegetables was cooked in already boiling demineralized water for $5 \mathrm{~min}$. Vegetable to water ratio was 1 : $4(\mathrm{~g}: \mathrm{ml})$. The remaining water after cooking was collected by draining the vegetable on a sieve. Both the cooked vegetables and the water remaining were each cooled, weighed, packaged in labelled plastic bags and rapidly frozen at $-30{ }^{\circ} \mathrm{C}$ in a cold air active freezer (Usifroid, Elancourt, France). The frozen liquid was subsequently kept at $-20^{\circ} \mathrm{C}$ while the frozen cooked vegetable was ground in liquid nitrogen. Both raw and cooked ground samples from the different treatments were each divided into three, packaged in labelled plastic containers and stored at $-80^{\circ} \mathrm{C}$ until analysis. Table 1 shows details of leafy vegetables used. Spinach was bought from a local market in Avignon.

Table 1. Selected Ghanaian Traditional Green Leafy Vegetables Studied.

\begin{tabular}{|c|c|c|c|c|}
\hline Scientific name & Family & English/Local name & Status of cultivation & Edible part and use \\
\hline Amaranthus hybridus & Amaranthaceae & Efan & Cultivated & Leaves used in soups ${ }^{4}$ \\
\hline Corchorus olitorius & Malvaceae & Jute mallow/Ayoyo & Cultivated & Leaves used in soups ${ }^{2}$ \\
\hline Launaea taraxacifolia & Asteraceae & Dandelion/African lettuce & Uncultivated & $\begin{array}{l}\text { The leaves-raw, cooked or dried are used in } \\
\text { soup, sauces, salads and teas }{ }^{3}\end{array}$ \\
\hline Nephrolepis undulate $s p$ & Oleandraceae & Fern in swampy/Aya & Tree, uncultivated & Leaves used in soups for lactating mothers ${ }^{3}$ \\
\hline Nephrolepis undulate p & Oleandraceae & Fern on palm tree/Aya & Tree, uncultivated & Leaves used in soups for lactating mothers \\
\hline Solanum macrocarpon & Solanaceae & Boma & Cultivated & $\begin{array}{l}\text { Both fruit and leaves of parent plant are used } \\
\text { in soups, sauces }{ }^{3} \text { Used in sauces and soups }{ }^{1}\end{array}$ \\
\hline $\begin{array}{l}\text { Xanthosoma } \\
\text { sagittifolium }\end{array}$ & Araceae & $\begin{array}{l}\text { Cocoyam } \\
\text { leaves/Kontomire }\end{array}$ & Cultivated & $\begin{array}{l}\text { Tubers and leaves are used. Leaves for } \\
\text { soups, stews }{ }^{3}\end{array}$ \\
\hline
\end{tabular}

${ }^{1}$ Duru et al. $[12,13],{ }^{2}$ Osonwa et al. [14], ${ }^{3}$ Personal communication, ${ }^{4}$ Oke [15], ${ }^{4}$ Mepha et al. [17] 


\subsubsection{Chemicals}

Ascorbic acid analysis: Ascorbic acid (>99\%), Trichloroacetic acid (>99\%) (TCA), 2, 2-Dipyridyl (>99\%), Orthophosphoric acid (85\%) $\left(\mathrm{H}_{3} \mathrm{PO}_{4}\right)$, Ferric chloride $(>99 \%)$ $\left(\mathrm{FeCl}_{3}\right)$, Sodium phosphate monobasic monohydrate $(>99 \%)$ $\left(\mathrm{NaH}_{2} \mathrm{PO}_{4}, 1 \mathrm{H}_{2} \mathrm{O}\right)$, DL-Dithiothreitol (>99\%) (DTT), Absolute Ethanol (100\%), Sodium Dihydrogen Phosphate Dodecahydrate $\quad(>99 \%) \quad\left(\mathrm{Na}_{2} \mathrm{HPO}_{4}, \quad 12 \mathrm{H}_{2} \mathrm{O}\right), \quad \mathrm{N}$ ethylmaleimide (>98\%) (NEM) and Ultrapure water.

Carotenoid analysis: Sodium Chloride $(\mathrm{NaCl}), \mathrm{n}-\mathrm{Hexane}$ (analytical grade), Dicholoromethane, ethyl acetat, methanol, and Methyl Terbutyl ether (all HPLC grade), lycopene, ultra pure water and zirconium beads

Folates: $0.1 \mathrm{M}$ phosphate buffer, ascorbic acid, chicken pancrease conjugase solution, $0.066 \mathrm{M}$ Tris buffer, 2-octanol, sodium borohydride, $5 \mathrm{M}$ acetic acid, formaldehyde, $\mathrm{HCl}, 5$ $\mathrm{M} \mathrm{NaOH}, 0.02 \mathrm{M}$ DL-dithiothreitol (DTT), $0.02 \mathrm{M}$ Trifluoroacetic (TFA) and ultra pure water

\subsection{Analytical Methods}

The homogenized samples stored at $-80^{\circ} \mathrm{C}$ were analyzed for micronutrients.

\subsubsection{Determination of Dry Matter}

About $3 \mathrm{~g}$ of samples was weighed into previously dried and weighed cans, dried at $70{ }^{\circ} \mathrm{C}$ until constant weight was achieved within $72 \mathrm{~h}$. Moisture content was estimated by difference in weights before and after drying.

\subsubsection{Determination of Ascorbic Acid}

Ascorbic acid was determined colorimetrically using a micro titration method as described by Stevens et al. [12] with little modification. In summary: $0.3 \mathrm{~g}-0.5 \mathrm{~g}$ of sample was added to eppendorf tube containing $600 \mu \mathrm{l}$ of $6 \%$ cold TCA, and immediately vortexed for about a minute to aid the extraction by the TCA. The sample was quickly centrifuged for $15 \mathrm{~min}$ at $4^{\circ} \mathrm{C}$ and $1300 \mathrm{~g}$. As described in the protocol used, DTT was used to reduce dehydroascorbic acid (DHAA) to ascorbic acid. The vitamin $\mathrm{C}$ was quantified at $525 \mathrm{~nm}$ on a spectrophotometer (Safas Xenius, Monaco). Duplicate analysis was done for each sample and quantification was determined by an external calibration against ascorbic acid (Sigma Aldrich, France). Results were expressed as the sum of ascorbic acid and dehydroascorbate, in $\mathrm{mg} / 100 \mathrm{~g}$ of fresh weight.

\subsubsection{Determination of $\beta$-carotene and Lutein}

Carotenoids were extracted from the powders using the micro extraction technique described by Bureau et al. [9].

About $500 \mathrm{mg}$ of sample was weighed into $2 \mathrm{ml}$ Eppendorf tube already containing about $80 \mu \mathrm{g}$ of $0.1 \mathrm{~mm}$ Zirconia beads and lycopene $\left(10-70 \mu \mathrm{l}\right.$ of a $0.2 \mathrm{mg} \mathrm{ml}^{-1}$ solution of lycopene in ethyl acetate served as internal standard) was added to the sample in the tube. Extraction was achieved by sequentially adding $100 \mu \mathrm{l}$ of saturated aqueous $\mathrm{NaCl}$ solution and $50 \mu \mathrm{l}$ of $\mathrm{n}$-hexane followed by $40 \mathrm{~s}$ agitation using a FastPrep ${ }^{\circledR}$ homogenizer (Thermo scientific, Waltham,
USA) and 2 min centrifugation at high speed (10 $000 \mathrm{~g}$ at $4^{\circ} \mathrm{C}$ ). About $200 \mu \mathrm{l}$ of dichloromethane was added following a similar agitation and centrifugation as done previously. Finally, $800 \mu \mathrm{l}$ of ethyl acetate was added to the sample, agitated for $5 \mathrm{~min}$ and centrifuged. The supernatant containing the carotenoids obtained was filtered for assay using reverse phase HPLC.

Quantification was done by HPLC-DAD (SPD-M20A Shimadzu Inc., Kyoto, Japan) using a C30 column (250×4.6 $\mathrm{mm}$, particle size $3 \mu \mathrm{m}$; YMC Co, Kyoto, Japan) under the following condition: elution at $30^{\circ} \mathrm{C}$, flow rate of $1.4 \mathrm{ml} \mathrm{min}$ ${ }^{1}$ and injection volume $20 \mu \mathrm{l}$ with a methanol-methyl tertbutyl ether (MTBE) gradients.

Lutein and $\beta$-carotene were quantified at $450 \mathrm{~nm}$ and lycopene (used as internal standard) at $503 \mathrm{~nm}$. Quantification was performed relative to the peak area of the internal standard (lycopene).

\subsubsection{Determination of Folate}

Folate was measured according to the method of Delchier et al. [18] with slight modifications. The process was in four main steps: extraction, deconjugation, transformation and purification.

\section{i. Extraction:}

$30 \mathrm{ml}$ of $0.1 \mathrm{M}$ phosphate buffer containing 1\% ascorbic acid was added to $10 \mathrm{~g}$ of sample and boiled in a water bath at $100^{\circ} \mathrm{C}$ for $10 \mathrm{~min}$ to achieve extraction. After cooling for $15 \mathrm{~min}$, the volume was adjusted to $50 \mathrm{ml}$ with phosphate buffer ( $0.1 \mathrm{M}$ containing $1 \%$ ascorbic acid) and centrifuged for $10 \mathrm{~min}$ at $5000 \mathrm{~g}$.

ii. Deconjugation: $1 \mathrm{ml}$ of chicken pancreas suspension at $10 \mathrm{~g} / \mathrm{l}$ was added to $10 \mathrm{ml}$ of extract and incubated at $37^{\circ} \mathrm{C}$ for $2 \mathrm{~h}$. This was to deconjugate polyglutamate forms of folate into mono- and di-glutamate.

iii. Chemical transformation of folates 5- $\mathrm{CH}_{3} \mathrm{THF}: 5 \mathrm{ml}$ of phosphate buffer with $0.4 \%$ ascorbic acid, $15 \mathrm{ml}$ of $0.066 \mathrm{M}$ Tris buffer, $1 \mathrm{ml}$ of 2-octanol and $10 \mathrm{ml}$ of sodium borohydride at $120 \mathrm{~g} / \mathrm{l}$ were gently added to the incubated extract to avoid effervescence. The content was stirred and allowed to stand for $10 \mathrm{~min}$. The $\mathrm{pH}$ of sample solution was adjusted to 7.4 with $5 \mathrm{M}$ acetic acid. $80 \mu \mathrm{l}$ of $37 \%$ formaldehyde and $10 \mathrm{ml}$ sodium borohydride were added slowly and the $\mathrm{pH}$ reduced to a value less than 1 with $37 \% \mathrm{HCl}$. The mixture was allowed to stand for $10 \mathrm{~min}$ and its $\mathrm{pH}$ adjusted back to 5 by gradually adding $5 \mathrm{M} \mathrm{NaOH}$ and sodium borohydride. The solution was left to stand for $20 \mathrm{~min}$ and later transferred into the $100 \mathrm{ml}$ volumetric flasks. Tris buffer was added to the volumetric flask to make it to the mark. The flasks were covered with parafilm and mixed thoroughly by shaking. The solution was filtered with a $10 \mathrm{ml}$ syringe attached to the 80 micron filters (with cellulose acetate membrane) into $15 \mathrm{ml}$ falcon tubes and labelled.

The series of chemical reactions were to convert all folate present in the deconjugated sample extracts to 5- 
methyltetrahydrofolic acid $\left(\mathrm{THF}-5 \mathrm{CH}_{3}\right)$ monosodium glutamate and / or diglutamate.

iv. Purification of folates - Transformed folate was purified by affinity chromatography with Folate Binding Protein, followed by columns condition using $5 \mathrm{ml}$ phosphate buffer $(0.1 \mathrm{M}, \mathrm{pH} 7) .10 \mathrm{ml}$ of sample solution was filtered through the column gel for elution of folates with $8 \mathrm{ml}$ eluent solution consisting of 0.02 M DL-dithiothreitol (DTT) and $0.02 \mathrm{M}$ trifluoroacetic acid (TFA) into a beaker containing $40 \mu \mathrm{l}$ of $60 \%$ $\mathrm{NaOH}$ and $200 \mu \mathrm{l}$ of $25 \%$ ascorbic acid. The volume was adjusted to $10 \mathrm{ml}$ with eluent solution. About $1 \mathrm{ml}$ of eluted folate solution was filtered with $0.45 \mu \mathrm{m}$ filters into HPLC chamber vials for quantification.

v. Folates quantification: With the use of HPLC equipped with fluorimetric detection (RF-10AXL, Shimadzu Inc., Kyoto, Japan), Column Licrospher ${ }^{\circledR}$ RP-18 Column 250 x $4.6 \mathrm{~mm}, 5 \mu \mathrm{m}$; Precolumn Guard 7.5 x $4.6 \mathrm{~mm}$ Licrospher ${ }^{\circledR} \mathrm{RP}-185 \mu \mathrm{m}$; column oven temperature: $30^{\circ} \mathrm{C}$; Autosampler Temperature: $4^{\circ} \mathrm{C}$ and a flow rate of $0.8 \mathrm{ml}$ per minute, $25 \mu \mathrm{l}$ of the eluted solution was injected. The mobile phases were: ultrapure Water $+0.1 \%$ formic acid (v/v) and acetonitrile.

\subsection{Statistics}

At least two replicate analyses of two or three separate aliquots of each vegetable sample were carried out for ascorbic acid, $\beta$-carotene and lutein. Folate samples were in duplicate. Data was summarized using means and standard deviations in MS Excel software (2010).

\section{Results and Discussion}

The mean micronutrients levels in the vegetables, both raw and boiled, have been presented in Tables 2 and 3, respectively. Table 4 has the mean micronutrient levels of microwaved vegetables.

From Tables 2 and 3, all the vegetables had increased moisture content after boiling as a result of water uptake from the surrounding cooking media. Water and watersoluble substances are exchanged through leaching and water absorption/uptake during boiling. This was shown in the higher moisture content of the boiled vegetables (Table 3) and the colour change in the water used to boil the vegetable (data not presented). Moisture contents of the raw vegetables studied were high $(75 \%$ for Nephrolepis undulata species found at swampy areas; $92 \%$ for spinach) in accordance with the knowledge that vegetables generally have high moisture. Vegetable consumption thus puts less stress on the digestive system because of the high moisture content, which will require less energy and water for digestion and nutrients assimilation.

Table 2. Ascorbic acid, beta-carotene, lutein and folate contents of raw green leafy vegetables (fresh weight).

\begin{tabular}{|c|c|c|c|c|c|}
\hline Vegetable name & Moisture (g) & $\begin{array}{l}\text { Vit C } \\
\mathrm{mg} / 100 \mathrm{~g}\end{array}$ & $\begin{array}{l}\beta \text {-carotene } \\
\mathrm{mg} / 100 \mathrm{~g}\end{array}$ & $\begin{array}{l}\text { Lutein } \\
\mathrm{mg} / 100 \mathrm{~g}\end{array}$ & $\begin{array}{l}\text { Total folate } \\
\mu \mathrm{g} / 100 \mathrm{~g}\end{array}$ \\
\hline Amaranthus hybridus & $87.3 \pm 1.5$ & $24 \pm 1.7$ & $10.4 \pm 0.85$ & $16 \pm 1.4$ & $73 \pm 2.3$ \\
\hline Corchorus olitorius & $82.0 \pm 0.1$ & $48 \pm 4.1$ & $6.4 \pm 0.18$ & $22 \pm 0.3$ & $89 \pm 5.8$ \\
\hline Launaea taraxacifolia & $90.8 \pm 0.9$ & $11 \pm 0.7$ & $7.5 \pm 0.19$ & $14 \pm 1.1$ & $60 \pm 6.5$ \\
\hline Nephrolepis undulate (found on palm trees) & $75.4 \pm 0.2$ & $161 \pm 3.2$ & $3.0 \pm 0.13$ & $21 \pm 1.0$ & $18 \pm 2.8$ \\
\hline Nephrolepis undulata species (found at swampy areas) & $74.8 \pm 0.6$ & $97 \pm 4.8$ & $4.9 \pm 0.10$ & $25 \pm 0.7$ & $74 \pm 5.6$ \\
\hline Solanum macrocarpon & $86.2 \pm 0.3$ & $21 \pm 2.1$ & $6.4 \pm 0.58$ & $32 \pm 2.4$ & $35 \pm 1.4$ \\
\hline Spinach & $92.1 \pm 0.1$ & $7 \pm 0.8$ & $4.1 \pm 0.04$ & $19 \pm 0.1$ & $146 \pm 5.2$ \\
\hline Xanthosoma sagittifolium & $84.0 \pm 0.7$ & $60 \pm 5.3$ & $4.7 \pm 0.79$ & $20 \pm 4.8$ & $99 \pm 3.4$ \\
\hline
\end{tabular}

Spinach* this spinach was not a traditional vegetable from Ghana, it was obtained from an open market in Avignon to compare All samples were analyzed in triplicates for ascorbic acid, duplicate for carotenoids and folate

\subsection{Vitamin C Content of Raw Vegetables}

The vitamin $\mathrm{C}$ content in the vegetables as reported in this study is a measure of reduced ascorbic acid and dehydroascorbic acid (DHA). Among the seven (7) TGLVs analysed (Table 2), vitamin C content was highest in the Nephrolepis undulata leaves that were harvested from the wild on palm tree followed by the same species harvested from swampy area. Corchorus olitorius and Xanthosoma saggitifolium leaves were the second group of vegetables with relatively high vitamin $\mathrm{C}$. The spinach from France had the least of vitamin $\mathrm{C}$ content as compared to the TGLVs from Ghana. This could be due to its high moisture content compared to the Ghanaian vegetables studied (Table 2). On the contrary, higher vitamin $\mathrm{C}$ contents $(36,39$ and 89 $\mathrm{mg} / 100 \mathrm{~g}$ ) were obtained for spinach and $50-60 \mathrm{mg} / 100 \mathrm{~g}$ for Amaranthus viridis [19, 20]. 19 and $25 \mathrm{mg} / 100 \mathrm{~g}$ Vitamin C has been reported for Amaranthus species [21] as well.
Xanthosoma saggitifolium in the present study had a higher vitamin $C$ content than that which was reported $(37 \mathrm{mg} / 100 \mathrm{~g})$ by Agbemafle et al. [22]. The study has shown wide variations of vitamin $\mathrm{C}$ among the studied green leafy vegetables and in comparison, with reported values in literature $[8,11]$. The variations could be attributed to differences in variety, method of analysis or pre-and postharvest factors such as agronomic practices, climatic conditions, maturation, harvesting method and storage, these factors are known to cause differences in vitamin $\mathrm{C}$ content of food crops [23].

Some of the richest sources of vitamin $\mathrm{C}$ are guava (228 $\mathrm{mg} / 100 \mathrm{~g})$, yellow bell pepper $(184 \mathrm{mg} / 100 \mathrm{~g})$, broccoli stalk (93/100 g), and mustard spinach $170 \mathrm{mg} / 100 \mathrm{~g}$ [24]. The raw Ghanaian TGLVs compared favourably to these well-known vegetables, especially the uncultivated tree green leaves, Nephrolepis undulata species. 


\subsection{Carotenoids: $\beta$-carotene and Lutein Content of Raw Vegetables}

Main carotenoids in the green leafy vegetables were lutein and $\beta$-carotene (Table 2), with variable relative proportions (Lutein/ $\beta$-carotene ranging from 1.6 to 6 ). The leaves of Solanum macrocarpon were particularly rich in lutein whereas, those of Amaranthus hybridus were high in $\beta$ carotene. Lutein concentration was lowest for Launaea taraxacifolia and highest for Solanum macrocarpon while Nephrolepis undulata harvested from palm tree and Amaranthus hybridus recorded the least and highest $\beta$ carotene contents, respectively. With the exception of Launaea taraxafolia and Amaranthus hybridus, all the other investigated vegetables had higher lutein concentrations than spinach. Similar trend was observed for $\beta$-carotene where all the vegetables with the exception of Nephrolepis undulate, had higher $\beta$-carotene than spinach.

In a similar study by Steiner-Asiedu et al. [25], $\beta$-carotene was found to be the predominant carotenoid followed by lutein in Solanum macrocarpon and Corchorus olitorius, although comparatively higher values of $\beta$-carotene (140.05 \pm 0.13 and $196.32 \pm 0.08 \mathrm{mg} / 100 \mathrm{~g})$ and lutein $(90.38 \pm 0.08$ and $112.75 \pm 0.05 \mathrm{mg} / 100 \mathrm{~g}$ ) were obtained in the raw samples. Slightly lower $\beta$-carotene content has been reported for Solanum macrocarpon $(5.5 \mathrm{mg} / 100 \mathrm{~g})$ and Corchorus olitorius (4.3 mg/100 g) [11].

In Malaysia, green vegetables such as Chinese mustard leaves, kale, lettuce, spinach and swamp cabbage contribute between 1.8-4.8 mg $\beta$-carotene/100 g edible portion. Chang et al. [20] obtained a range of 0.08-9.2 mg/100 g $\beta$-carotene for green vegetables while Pakistan et al. [26] in their studies found out that dark green vegetables have more $\beta$-carotene than other vegetables. The authors obtained about twice the $\beta$-carotene content in spinach compared to the present study. The variations in carotenoid concentrations among the vegetables could be due to differences in moisture content, variety, maturity of samples and extraction method.

Daily recommended allowance (RDA) for vitamin A range from 500 to $600 \mu \mathrm{g}$ retinol equivalent for female adults and adolescent/male adults. Using the FAO / IN FOODS [27] vitamin $A$ and $\beta$-carotene conversion factor of $1: 12$ and the maximum recommended safe intake of $600 \mathrm{RE}$, the TGLVs could provide between 40 to $140 \%$ of vitamin A RDA when consumed raw. Results for $\beta$-carotene content of the vegetables studied support the observation of Jaarsveld et al. [11], that green leafy vegetables are potential sources of $\beta$ carotene and could be utilized as a cheaper and a more sustainable means of mitigating vitamin A deficiency. The high concentrations of $\beta$-carotene in Amaranthus hybridus, Launaea taraxifolia and Solanum macrocarpon in particular could be exploited for provision of vitamin A in diets. In India, $90 \%$ of $\beta$-carotene is obtained from consumption of green leafy vegetables [11]. Launaea taraxifolia for instance is gradually gaining popularity for salads and in tea production (Personal communication), thus, conscious effort towards awareness creation for increase and diversified consumption of these vegetables is essential.

Information on the lutein content of TGLVs in Ghana is scarce [25]. Djuikwo et al. [28] studied the lutein content of tropical leafy vegetables from Cameroon and reported similar results to the values obtained in this study. Judging from the important function of lutein in protecting against the development of age-related macular degeneration (AMD) [29] and in improving visual function, consumption of the TGLVs in this study could be promoted for potential health benefits. Intake of $6-10 \mathrm{mg} /$ day lutein is reported to have positive effects. Thus, the obtained 14 to $32 \mathrm{mg} / 100 \mathrm{~g}$ of lutein in the investigated vegetables shows high potential of obtaining enough daily needs of lutein provided the lutein is bioavailable and the vegetables are consumed raw.

\subsection{Folate}

The studied vegetables had total folate concentrations between 18 and $99 \mu \mathrm{g} / 100 \mathrm{~g}$ for Nephrolepis undulata and Xanthosoma saggitifolium respectively (Table 2). Spinach, a well-known vegetable for high folate content, had concentrations of $147 \mu \mathrm{g} / 100 \mathrm{~g}$. Similar results for raw spinach have been reported by other researchers; Delchier et al. [30] $(1.49 \mathrm{mg} / \mathrm{kg})$ and Konings et al. [31] (1 mg/kg). Similar folate concentrations have been reported by Ejoh et al. [32]. According to Ogle et al. [33], green leafy vegetables are considered good sources of dietary folate when their concentrations are higher than $50 \mu \mathrm{g} / 100 \mathrm{~g}$ edible portion of the fresh vegetable. All the vegetables studied, with the exception of Nephrolepis undulate (found on palm trees) and Solanum macrocarpon, could be considered good sources of folate. In fresh form, Xanthosoma sagittifolium, which had the highest folate concentration among the green leafy vegetables from Ghana, will contribute about $25 \%$ of folate RDA (400 $\mu \mathrm{g} /$ day for adults) when $100 \mathrm{~g}$ is consumed, while spinach will contribute about $36 \%$. Shohag et al. [34] reported that for one cup serving of different vegetables, $5-25 \%$ of folate RDA was provided for adults while pregnant women would gain $3-17 \%$. Folate supplementation has been the norm for Ghanaian pregnant women aimed at preventing neural tube defect of newborns. The studied TGLVs have the potential to contribute to folate needs of consumers.

\subsection{Impact of Boiling on the Vitamin $C$, $\beta$-carotene, Lutein and Folate Content of Green Leafy Vegetables}

\subsubsection{Vitamin C Content of Boiled Vegetables}

Vitamin $\mathrm{C}$ concentrations reduced drastically by $68 \%$ and 93\% for Solanum macrocarpon and Launaea taraxacifolia respectively, when the vegetables were boiled for $5 \mathrm{~min}$ in vegetable to water ratio of 1: 4 (Table 3). Spinach had the least vitamin C loss (44\%) when boiled under the same conditions. Similar huge losses of vitamin $\mathrm{C}$ by blanching boiling or cooking in water have been reported in the literature $[9,22,25$, 30]. As expected, the general trend was that samples with higher vitamin $\mathrm{C}$ in the raw vegetables retained higher vitamin C levels when boiled while Lunea taraxacifolia nearly lost all of its vitamin $\mathrm{C}$ content. Vitamin $\mathrm{C}$ is heat labile and can easily 
oxidize to dehydroascobic acid, which has some vitamin $\mathrm{C}$ activity but can also be further hydrolysed to give diketogulonic acid with total loss of its biological activity [23]. Losses could however be minimized if vegetables are steamed [8] or boiled in smaller quantities of water [9].

Even with reduced vitamin C concentration, a $100 \mathrm{~g}$ portion of the cooked vegetables could contribute up to $90 \%$ of vitamin C RDA [35] with Nephrolepis undulata leaves contributing the highest. Knowing the wound healing properties of vitamin C [19], Nephrolepis undulate leaves (traditionally used in Ghana to prepare soups for lactating mothers) could contribute to general good health and healing of wounds from childbearing. Cooked Xanthosoma saggitifolium leaves are also widely consumed in Ghana, especially those in forest areas, could also contribute about 40 percent of vitamin C RDA [35]. Considering the vital roles of vitamin $\mathrm{C}$ in human nutrition and the associated diseases resulting from its deficiency, indigenous vegetables that have appreciable contents when cooked should be promoted as part of everyday meals.

Table 3. Ascorbic acid, $\beta$-carotene, lutein and folate contents of boiled green leafy vegetables (nutrient per $100 \mathrm{~g}$ of edible portion (EP), fresh weight).

\begin{tabular}{|c|c|c|c|c|c|c|c|c|c|}
\hline Vegetable name & $\begin{array}{l}\text { Moisture } \\
\text { (g) }\end{array}$ & $\begin{array}{l}\text { Vit C mg/100 } \\
\mathrm{g}\end{array}$ & $\begin{array}{l}\% \\
\text { loss } \\
\end{array}$ & $\begin{array}{l}\beta \text {-carotene } \\
\mathrm{mg} / 100 \mathrm{~g}\end{array}$ & $\begin{array}{l}\text { \% loss } \\
\text { / gain }\end{array}$ & $\begin{array}{l}\text { Lutein } \\
\mathrm{mg} / 100 \mathrm{~g}\end{array}$ & $\%$ loss & $\begin{array}{l}\text { Total folate } \\
\mu \mathrm{g} / 100 \mathrm{~g}\end{array}$ & $\begin{array}{l}\text { \% loss / } \\
\text { gain }\end{array}$ \\
\hline Amaranthus hybridus & $91.5 \pm 0.1$ & $3.3 \pm 1.1$ & 87 & $24.9 \pm 0.2$ & -76 & $9.6 \pm 0.4$ & 41 & $46 \pm 1.8$ & -37 \\
\hline Corchorus olitorius & $92.9 \pm 0.1$ & $9.3 \pm 2.3$ & 81 & $11.9 \pm 0.5$ & -81 & $4.4 \pm 0.1$ & 80 & $\mathrm{n} / \mathrm{d}$ & $\mathrm{n} / \mathrm{d}$ \\
\hline Launaea taraxacifolia & $93.8 \pm 0.1$ & $0.7 \pm 0.7$ & 94 & $43.0 \pm 3.0$ & -43 & $9.7 \pm 0.6$ & 28 & $\mathrm{n} / \mathrm{d}$ & $\mathrm{n} / \mathrm{d}$ \\
\hline Nephrolepis undulate (found on palm trees) & $86.8 \pm 0.1$ & $36.1 \pm 16.1$ & 78 & $24.3 \pm 2.6$ & -18 & $12.4 \pm 1.8$ & 41 & $\mathrm{n} / \mathrm{d}$ & $\mathrm{n} / \mathrm{d}$ \\
\hline Nephrolepis undulata species (SP*) & $83.4 \pm 0.4$ & $15.5 \pm 9.4$ & 84 & $34.4 \pm 4.7$ & -29 & $18.0 \pm 2.6$ & 29 & $\mathrm{n} / \mathrm{d}$ & $\mathrm{n} / \mathrm{d}$ \\
\hline Solanum macrocarpon & $90.7 \pm 0.2$ & $6.6 \pm 0.3$ & 68 & $69.7 \pm 0.8$ & +8 & $17.4 \pm 0.5$ & 45 & $36 \pm 0.6$ & +2.3 \\
\hline Spinach* & $93.8 \pm 0.3$ & $4.0 \pm 0.5$ & 45 & $35.0 \pm 0.8$ & -15 & $15.8 \pm 0.3$ & 17 & $\mathrm{n} / \mathrm{d}$ & $\mathrm{n} / \mathrm{d}$ \\
\hline Xanthosoma sagittifolium & $90.3 \pm 0.1$ & $15.6 \pm 4.0$ & 74 & $25.6 \pm 1.2$ & -45 & $11.5 \pm 0.6$ & 42 & $95 \pm 11.3$ & -4 \\
\hline
\end{tabular}

n/d- not determined; $\mathrm{P}^{*}$ and SP* represent location where the Nephrolepis undulate was found: 'on palm tree' and 'swampy area' Spinach* This spinach is not a traditional vegetable from Ghana, it was obtained from an open market in Avignon to compare All samples were analyzed in triplicates for ascorbic acid, duplicate for carotenoids and folate

\subsection{2. $\beta$-carotene and Lutein Content of Boiled Vegetables}

Similar to vitamin $C$, losses were observed in $\beta$-carotene upon cooking the vegetables. However, losses were less pronounced in majority of the vegetables compared to vitamin $\mathrm{C}$ losses. Spinach comparatively recorded lower $\beta$-carotene losses (15\%) when boiled than the other studied vegetables (Table 3) whose losses ranged from 18 to $80 \%$, for Nephrolepis undulata harvested from palm tree and Corchorus olitorius, respectively. An exception was observed for Solanum macrocarpon where the $\beta$-carotene rather increased $(8 \%)$ when boiled. Pressure cooking, microwaving, steaming and blanching has resulted in increased extractability of carotenoids.

Up to $130 \%$ increased carotenoids as a result of boiling, steaming, blanching and microwaving green leafy vegetables have been reported by Okpalamma et al. [36] and Bureau et al. [9]. The higher $\beta$-carotene concentrations in boiled Solanum macrocarpon could be due to difficulty in extracting carotenoids in its raw samples. Unlike the raw vegetables, boiling might have caused break down of the plant cell wall which allows for the leakage of cell contents thus releasing more $\beta$-carotene into solution [37]. According to Rodriguez-Amaya [38], lower $\beta$ carotene in raw vegetables is attributed to food component complexes which hinders the rate of extraction as compared to boiled vegetables. It could also result from loss of water and soluble solids, which can lead to release of more carotenoids per unit weight of sample [9]. Moderate cooking may increase the availability of $\beta$-carotene in vegetables but repeated cooking at high temperature rather destroys most pro-vitamins.

Hundred-gram $(100 \mathrm{~g})$ portions of $\beta$-carotene in the studied boiled vegetables, could contribute to between 17 to $97 \%$ of RDA for vitamin A. Vitamin A deficiency (VAD) continues to be a severe health problem in Ghana especially for children and women. The studied traditional green leafy vegetables could play a significant role in addressing VAD health problems if consumed frequently, together with some fat component [38].

Lutein concentrations in boiled vegetables had minimal losses with the exception of Corchorus olitorius, which had about $80 \%$ loss. Spinach had the least lutein loss after boiling, the percentage loss being lower than the observed loss for $\beta$ carotene. This was not the expectation as lutein is more water soluble than $\beta$-carotene. However, Granado et al. [39] also found higher retention of lutein in boiled spinach and amaranth samples. Chang et al. [20] observed that lutein in spinach increased after boiling for 4 min but reduced after 8 min of boiling while Okpalamma et al. [36] reported up to $76 \%$ increase in lutein content with similar cooking conditions for Telfaria occidentalis.

\subsubsection{Folate Content in Boiled Vegetables}

Folate concentration remained virtually unchanged when boiled for Solanum macrocarpon and Xanthososma sagittifolium as compared to Amaranthus hybridus, which recorded about 37\% losses. The obtained losses in these vegetables to boiling are comparable to the reported for green beans but comparatively lower in many of the reported cases by other authors. Boiling caused folate loss of $26 \%$ in green beans and 94\% in hashed spinach [9]. Similarly, Mckillop et al. [40] observed significant decreases of folate (51\% and $56 \%$ respectively) for spinach and broccoli when boiled.

Retention between 14-99\% as a result of cooking has been observed depending on both the type of food involved and the method of processing [40]. Steam blanching has been observed to have higher folate retention compared to water blanching [40]. According to Delchier et al. [30], folates readily leach into water due to their hydrophilic property and 
the losses during boiling were found to be accounted for in the boiling liquid. Generally, cooking methods with indirect contact with the food such as pressure cooking are better than boiling in terms of folate retention [41]. Thus, in advocating for increased consumption of vegetables with high folate content, practical advice on cooking methods especially those that limit water contact with the vegetables should be emphasized for optimal benefits.

\subsection{Impact of Microwave Cooking on the Vitamin C, $\beta$-carotene, Lutein and Folate Content of the Leafy Vegetables}

Table 4 presents the results of the microwaved samples.
Unlike boiling the vegetables for $5 \mathrm{~min}$, they were microwaved for $10 \mathrm{~min}$ to obtain similar cooked texture. The losses due to microwave cooking varied for the different micronutrients determined. Vitamin C losses for Amaranthus hybridus, Solanum macrocarpon and Xanthosoma sagittifolium, were higher than the losses due to boiling (Tables 3, 4). Losses between 78 and 91\% were observed for Solanum macrocarpon and Amaranthus hybridus. Losses of $\beta$-carotene between 0.62 and $61 \%$ were observed for Xanthoéoma sagittifolium and Amaranthus hybridus respectively due to microwave cooking, and these were lower than losses due to boiling.

Table 4. Ascorbic acid, beta carotene, lutein and folate contents of microwaved Ghanaian traditional leafy vegetables (fresh weight).

\begin{tabular}{|c|c|c|c|c|c|c|c|c|c|}
\hline Vegetable name & $\begin{array}{l}\text { Moisture } \\
\text { (g) }\end{array}$ & $\begin{array}{l}\text { Vit C } \\
\mathrm{mg} / 100 \mathrm{~g}\end{array}$ & $\begin{array}{l}\% \\
\text { loss } \\
\end{array}$ & $\begin{array}{l}\beta \text {-carotene } \\
\mathrm{mg} / 100 \mathrm{~g}\end{array}$ & $\begin{array}{l}\% \\
\text { decrease }\end{array}$ & $\begin{array}{l}\text { Lutein } \\
\mathrm{mg} / 100 \mathrm{~g}\end{array}$ & \% loss/gain & $\begin{array}{l}\text { Total folate } \\
\mu \mathrm{g} / 100 \mathrm{~g}\end{array}$ & $\%$ gain \\
\hline Amaranthus hybridus & $81.8 \pm 0.1$ & $2.3 \pm 0.3$ & 91 & $4.1 \pm 0.0$ & 61 & $14.6 \pm 0.4$ & -11 & $80 \pm 1.9$ & +9 \\
\hline Launaea taraxacifolia & $87.2 \pm 0.1$ & $\mathrm{n} / \mathrm{a}$ & $\mathrm{n} / \mathrm{a}$ & $6.9 \pm 0.5$ & 8 & $13.7 \pm 1.3$ & +1 & $\mathrm{n} / \mathrm{a}$ & $\mathrm{n} / \mathrm{a}$ \\
\hline Xanthosoma sagittifolium & $77.4 \pm 0.0$ & $8.4 \pm 1.8$ & 86 & $4.6 \pm 0.1$ & 1 & $20.4 \pm 2.6$ & +3 & $124 \pm 4.6$ & +26 \\
\hline
\end{tabular}

nd- not determined

All samples were analyzed in triplicates for ascorbic acid, duplicate for carotenoids and folate

Microwaving can profoundly affect both the texture and nutritional value of vegetables. Thermal treatment leads to various carotenoid losses and increasing the temperature in particular leads to significantly higher losses of some carotenoids [42]. The observed losses could be due to the high temperatures used in microwave ovens and the relatively longer time (10 $\mathrm{min})$ in which the vegetables were microwaved to acceptably cooked levels.

In the case of lutein, microwave cooking had less impact with the highest loss of $49 \%$ in Solanum macrocarpon while Launaea taraxacifolia and Xanthosoma saggitifolium had negligible changes (Table 2) in comparison to the 90 and $78 \%$ losses detected in boiling (Table 3). Lutein as observed in this study is reported to be more resistant to heat treatment and it is not liberated in aqueous phase [30]. Given the good concentrations of lutein in the vegetables, promoting their consumption is important, especially where age-related mucular diseases (AMDs) is prevalent.

Folate concentrations measured in the microwaved vegetables were higher than in the raw vegetables, probably as a result of water loss during microwaving (Table 4), which leads to more folate per unit weight of the vegetable. All the three microwaved samples assessed for folate concentrations had increases ranging from about 9 to as high as $200 \%$ for Amaranthus hybridus and Solanum macrocarpon (Table 4) compared to the raw samples (Table 2). Microwave cooking, which is a cooking method with indirect contact with food, was reported to be better than boiling in terms of folate retention [43].

The variation in retention or losses of micronutrients is influenced by type of vegetables, environmental conditions, cooking method and interaction between the cooking method and the type of vegetables [20]. In general, losses of the micronutrient to microwave cooking were lower when compared to the losses due to boiling. The minimal losses compared to boiling was expected as many studies have shown similar or better retention of nutrients for microwave cooking than the same product prepared conventionally. Using recommended procedures for microwave cooking and reheating would result in products that are satisfying from both a sensory and nutritional standpoint [43]. Contradictory results have however been reported on the retention of nutrients by microwave cooking due to different conditions (time, power, and added water) that are employed. Vitamin C is reported to have the highest losses probably as a result of thermal degradation during microwave cooking [44] as observed in this study.

\section{Conclusion}

The traditional green leafy vegetables studied had high and varied micronutrient contents, comparable to established good sources. Amaranthus hybridus, Lunear taraxifolia and Solanum macrocarpon had high concentrations of $\beta$-carotene, whereas all the vegetables had appreciable levels of lutein. Xanthosoma sagittifolium and Nephrolepis undulate could represent good or nonnegligible sources of vitamin $\mathrm{C}$ and folate, respectively. Both boiling and microwave cooking led to drastic losses of the micronutrient; however, cooked vegetables could contribute significantly to RDA of the various tested micronutrients. Consistent and varied consumption of indigenous vegetables stand a huge potential to solving micronutrient deficiency health problems, especially that of vitamin A. Improved cooking methods for enhanced micronutrients retention should be advocated for. 


\section{Acknowledgements}

This work was supported by Agropolis Fondation through the Investissements d'avenir programme (ANR-10LABX0001-01) under the reference ID 1204-001 and 1204002 for the internship of SIE and FWMD at Institut National de la Recherche Agronomique (INRA), Avignon, France. AWARD fellowship provided the platform and opportunity of a 6-month research attachment/advanced science training in INRA to conduct this research; Kwame Nkrumah University of Science and Technology (KNUST) granted the permission to participate in the Advanced Science training during which this study was carried out. The authors extend their thanks to Caroline Garcia, Marielle Bogé and Sylvie Bureau for their help and training.

\section{References}

[1] Darnton-Hill, I., Webb, P., Harvey, P. W., Hunt, J. M., Dalmiya, N., Chopra, M., Ball, M. J. Bloem, M. W. and de Benoist, B. (2005) 'Micronutrient deficiencies and gender: social and economic cost', The American Journal of Clinical Nutrition, 81 (5), p. 1198S-1205S. doi: 81/5/1198S [pii].

[2] Smith, F. I. and Eyzaguirre, P. (2007). African leafy vegetables; their role in the World Health Organaization's global fruit and vegetables initiative. Available from http://space.library.utoronto.ca/handle/1807/55368.

[3] Amo-Adjei J, Kumi-Kyereme A (2014) Fruit and vegetable consumption by ecological zone and socioeconomic status in Ghana. Journal of Biosocial Science 47 (05): 1-19.

[4] Uusiku, N. P., Oelofse, A., Duodu, K. G., et al. (2010). Nutritional value of leafy vegetables of sub-Saharan Africa and their potential contribution to human health: a review. J. Food Comp Anal, 23 (6): 499-509.

[5] Darkwa S, D A A (2013). The use of indigenous green leafy vegetables in the preparation of Ghanaian dishes. Journal of Food Processing and Technology, 04 (12).

[6] Gupta, S., Jyothi, L. A, Manjunath, M. N., et al. (2005). Analysis of nutrient and antinutrient content of underutilized green leafy vegetables. LWT-Food Science and Technology, 38 (4): $339-45$

[7] Delchier, N., Herbig, A. L., Rychlik, M. and Renard, C. M. G. C. (2016). Folates in Fruits and Vegetables: Contents, Processing, and Stability. Comprehensive Reviews in Food Science and Food Safety, 15: 506-528. doi: 10.1111/15414337.12193

[8] Amusan, E. A., Ejoh, S. I., and Akinyele, I. O. (2015). Effect of boiling and steaming methods on the ascorbic acid content of wild and cultivated indigeneous green leafy vegetables found in Ibadan, Oyo State. Nigerian Journal of Nutrition Science, 36 (2): 59-63.

[9] Bureau S, Mouhoubi S, Touloumet L, Garcia C, Moreau F, Bedouet V and Renard C M G C (2015). Are folates, carotenoids and vitamin $\mathrm{C}$ affected by cooking? Four Domestic procedures are compared on a large diversity of vegetables. LWT-Food Science and Technology, 64: 735-741.

[10] Schonfeldt, H C. and Pretoriuos, B. (2011). The nutrient content of five traditional South African dark green leafy vegetables - A preliminary study. Journal of Food Composition and Analysis 28 (8): 1141-6.

[11] Jaarsveld P V, Faber M, Heerden I V, Wenhold F, Jansen W, Rensburg V, Averbeke W V (2014). Nutrient content of eight African leafy vegetables and their potential contribution to dietary reference intakes. Journal of Food Composition and Analysis 33 (1): 77-84.

[12] Duru, M., Tallowin, J. and Cruz, P. (2005). Functional diversity in low input grassland farming systems: characterization, effect and management. Agronomy Research 3: $125-138$

[13] Osonwa, U., Uronnachi, E., Umeyor, C. and Onwuzuligbo, C. (2012). Physicotechnical properties of paracetamol tablets formulated with the gum from the fresh leaves of corchorus olitorius. International Journal of Pharmaceutical Sciences and Research. 3. 2676-2679.

[14] Oke, O. L. 1983. Amaranth. In "Handbook of Tropical Foods," ed. H. T. Chan Jr., p. 1-2. Marcel-Dekker, Inc., New York.

[15] Mepha, H. D., Eboh, L. and Banigbo, D. E. B. (2007). Effect of processing treatments on the nutritive composition and consumer acceptance of some Nigerian edible leafy vegetables. African Journal of Food Agricultural Nutrition Development, 7 (1): 1-18.

[16] Duru, M., Amadi, C., Ugbogu, A., Eze, A. and Amadi, B. (2012). Phytochemical, vitamin and proximate composition of Dacryodes edulis fruit at different stages of maturation. Asian Journal of Plant Science and Research 2 (4): 437-441.

[17] Stevens R, Buret M, Garchery C, Yolande Carretero A, Causse $\uparrow M$ (2006). Technique for rapid, small-scale analysis of vitamin $\mathrm{C}$ levels in fruit and application to a tomato mutant collection. Journal of Agricultural and Food Chemistry 54 (17): 6159-6165.

[18] Delchier, N., Ringling, C., Le Grandois, J., Aoudé-Werner, D., Galland, R., Georgé S., Rychlik, M. and Renard, C. M. (2013). Effects of industrial processing on folate content in green vegetables. Food Chemistry, 139 (1-4): 815-24. doi: 10.1016/j.foodchem.2013.01.067.

[19] Ogunlesi M, Okiei W, Azeez L, Obakachi V, Osunsanmi M, Nkenchor G (2010). Vitamin C contents of tropical vegetables and foods determined by voltammetric and titrimetric methods and their relevance to the medicinal uses of the plants. International Journal of Electrochemical Science, 5: 105-115.

[20] Chang S K, Nagendra P K, Amin I (2013). Carotenoids retention in leafy vegetables based on cooking methods. International Food Research Journal, 20 (1): 457-465.

[21] Raju M, Varakumar S, Lakshminarayana R, Krishnakantha T P, Baskaran V (2007). Carotenoid composition and vitamin A activity of medicinally important green leafy vegetables. Food Chemistry 101 (4): 1598-1605.

[22] Agbemafle R, Obodai EA, Adukpo GE, Amprako DN (2012) Effects of boiling time on the concentrations of vitamin $\mathrm{c}$ and beta-carotene in five selected green vegetables consumed in Ghana. Advances in Applied Science Research, 3 (5): 28152820 .

[23] Lee S K, Kader A A (2000). Preharvest and postharvest factors influencing vitamin $\mathrm{C}$ content of horticultural crops. Postharvest Biology and Technology 20 (3): 207-220. 
[24] Ellong, E. N., Billard, C., Adenet, S., Rochefort, K. (2015). Polyphenols, Carotenoids, Vitamin C Content in Tropical fruits and vegetable and impact of processing methods. Journal of Food and Nutrition Sciences. p. 299-313. doi: 10.4236/fns.2015.63030.

[25] Steiner-Asiedu M, Agbemafle I, Setorglo J, Danquah A O, Anderson A K (2014). Carotenoids content of Corchorus olitorius and Solanum macrocarpon - commonly used Ghanaian vegetables. International Food Research Journal, 21 (5): 2063-2067.

[26] Pakistan P, Nauman Ahamad M, Saleemullah M, Ullah Shah H, Khalil I A, Saljoqi A (2007). Determination ofcarotene content in raw vegetatbles using high performance liquid chromatography. Sarhad Journal of Agriculture 23 (3): 767770 .

[27] FAO / IN FOODS. (2012). In Guidelines Guidelines for Converting Units, Denominators and Expressions (p. A-6. (2010a), 2010. A-6. (2010b), 2010. A-6. (2010).

[28] Djuikwo V N, Ejoh R A, Gouado I, Mbofung C M and Tanumihardjo S A (2011). Determination of major carotenoids in processed tropical leafy vegetables indigenous to Africa. Food and Nutrition Sciences 2: 793-802.

[29] SanGiovanni J P, Chew E Y, Clemons T E, et al. (2007). The relationship of dietary lipid intake and age-related macular degeneration: A case-control study in the Age-Related Eye Disease Study. Archives of Ophthalmology, 125 (5): 671-679.

[30] Delchier N, Reich M, Renard C M G C (2012). Impact of cooking methods on folates, ascorbic acid and lutein in green beans (Phaseolus vulgaris) and spinach (Spinacea oleracea). LWT - Food Science and Technology 49 (2): 197-201.

[31] Konings E J M, Roomans H H S, Dorant E, Goldbohm R A, Saris W H M, van den Brandt P A (2001). Folate intake of the Dutch population according to newly established liquid chromatog- raphy data for foods. American Journal of Clinical Nutrition, 73 (4): 765-76.

[32] Ejoh, S. I., Wireko-Manu, F. D., Page, D. and Renard, C. M. G C. (2019). Traditional green leafy vegetables as underutilized sources of micronutrients in a rural farming community in South-west Nigeria I: estimation of vitamin C, carotenoids and mineral contents. South African Journal of Clinical Nutrition, pp. 1-6. DOI: 10.1080/16070658.2019.1652963.

[33] Ogle, B., Dao, H., Generose, $\mathrm{M}$ and Leif, H. (2001). Micronutrient composition and nutritional importance of gathered vegetables in Vietnam. International Journal of Food Sciences and Nutrition, 52: 485-99. DOI: 10.1080/713671806.
[34] Shohag M J I, Yanyan W, Ning Y, Lingli L, Jie Z, Zhenli H, Johan P, Xiaoe Y (2012). Folate Content and Composition of Vegetables Commonly Consumed in China. Journal of Food Science 77 (11): 239-245.

[35] World Health Organization and Food and Agriculture Organization of the United Nations (2004). Vitamin and mineral requirements in human nutrition: report of a joint FAO/WHO expert consultation, Bangkok, Thailand

[36] Okpalamma F, Ojimelukwe P C, Mazi E A (2013). Postharvest storage and processing changes in carotenoids and micronutrients in fluted pumpkin (Telferia occidentalis Hook F.). IOSR Journal of Agriculture and Veterinary Science 6 (4): 34-39.

[37] Liu Y, Perera C O, Suresh V (2007). Comparison of three chosen vegetables with others from South East Asia for their lutein and zeaxanthin content. Food Chemistry 101 (4): 15331539.

[38] Rodriguez-Amaya D B (1997). Carotenoids and Food Preparation: The Retention of Provitamin A Carotenoids in Prepared, Processed, and Stored Foods, OMNI/USAID, Washington.

[39] Granado F, Olmedilla B, Blanco I, Rojas-Hidalgo, E (1992). Carotenoid composition in raw and cooked Spanish vegetables. Journal of Agricultural and Food Chemistry, 40 16): 21352140 .

[40] McKillop D J, Pentieva K, Daly D, Mcpartlin J M, Hughes J, Strain, J J, Scott J M, Mcnulty, H. (2002). The effect of different cooking methods on folate retention in various foods that are amongst the major contributors to folate intake in the UK diet. British Journal of Nutrition, 88: 681-688.

[41] Dang J (2000). Folate retention in selected processed legumes. Food Chemistry 68 (3): 295-298.

[42] Mertz C, Brat P, Caris-Veyrat C, Gunata Z (2010). Characterization and thermal stability of carotenoids and vitamin $\mathrm{C}$ of tamarillo fruit (Solanum betaceum Cav.). Food Chemistry 119 (2): 653-659.

[43] Klein B P (1989). Retention of nutrients in microwave-cooked foods. Boletín de La Asociación Médica de Puerto Rico 81 (7): 277-9. Retrieved from http://www.ncbi.nlm.nih.gov/pubmed/2775405.

[44] López-Berenguer C, Carvajal M, Moreno D A, GarcíaViguera C (2007). Effects of microwave cooking conditions on bioactive compounds present in broccoli inflorescences. Journal of Agricultural and Food Chemistry 55 (24): 1000110007. 